\title{
FUZZY ILLUSIONS: REALITY AND THE SUBJECT IN ERIC KRAFT'S «CALL ME LARRY»'
}

\author{
Violeta Delgado Crespo \\ Universidad de Zaragoza
}

«Wishful thinking», said Raskolnikov. «That's just a way of drawing. The artist uses a few quick strokes of the pen to suggest that the shade is down without inking in the whole shade. We had that in art class already. It's just an artist's trick. It's not really meant to represent anything. You only see a woman there because you want to.» He jabbed me in the ribs. (Raskolnikov to Peter Leroy in "Call Me Larry")

(Kraft 1992a: 348) ${ }^{2}$

\section{ABSTRACT}

In much contemporary fiction, the questioning of our inherited notions of the subject as an autonomous, unified individual, and reality as the clearly recognisable world in which we live has resulted in many cases in the disappearance of plot in its Aristotelian conception: as the first and most important dramatic element in the novel in this case. However, some contemporary American writers

1 The research carried out for the writing of this paper has been financed by the Gobierno de Navarra (Orden Foral 667/1995).

2 Henceforth cited in the text as CL. 
choose to recuperate a realistic mode of storytelling, a realism which is nevertheless postmodernist for its preoccupation with language and its questioning of reality and the subject. This "postmodern realism" would be said to be the mode in which the whole of Eric Kraft's work has been conceived. In "Call Me Larry", one of the novellas that make Little Follies (1992), the boundaries between the three ontologies where the three authors belong - the "real» Eric Kraft, and the two fictional authors, Peter Leroy and Roger Drake--, and even the figures of the three authors themselves, are craftily blurred, only to be re-constructed for the sake of the story, inviting the reader to suspend his/her disbelief and enjoy storytelling.

The abandonment of mimesis is one of the main characteristics of postmodernist fiction. Realism has been exposed as a mode, a way to perceive, understand and report on what has come to be called the "world outside" or the "real world", the place where we think we live but to which we cannot have direct access. The recognition of the importance of language not only as a mediator that is constantly deferring the possibility of getting to know the «world outside», but also as the producer of this world has resulted in the production of a new type of fiction that Patricia Waugh calls "metafiction» ${ }^{3}$ (Waugh, 1984). This type of fiction asserts the impossibility of holding the mirror up to reality and resolves to examine both itself and human perception of the world as an artefact. Metafiction has brought about a reversal in the direction of literary criticism. A text can no longer be interpreted through elements or structures drawn from the «real world» but intrinsically, and the «real world» has to be understood as a text, as a construction produced according to specific conventions. The result is narcissism and self-consciousness in fiction (Stonehill, 1988), a renewed preoccupation with language and an obsessive interest in breaking the illusion of mimesis by attracting attention to the text's fictional status. This fiction is created in the light of the demythologising of the concept of the subject. Both structuralists and post-structuralists agree in their critique of the human subject (Sarup, 1988). The subject, a humanist conception, is deconstructed and reduced to fragments (Hutcheon, 1988). In contemporary fiction there is the risk that endless playfulness with its own limits and the dissolution of character may lead to the disappearance of plot in the novel. It

${ }^{3}$ PATRICIA W AUGH defines «metafiction» as «[the] term given to fictional writing which selfconsciously and systematically draws attention to its status as an artefact in order to pose questions about the relationship between fiction and reality.» (Waugh, 1990: 2). 
looks as if plot is going to dissolve together with our stability or to become a pretext for a narcissistic self-indulging practice (Seed, 1991).

However plot and mimesis have not been eradicated. Some American writers recuperate the realistic mode of narration in their fiction:

In spite of the important notion of radical undecidability in postmodern culture, in the late 1970 s a certain number of contemporary American novelists already abandoned radical metafictional techniques that were in consonance with poststructuralist views, for the benefit of a new type of realism that is, nevertheless, still postmodernist in its emphasis on some other recent issues, such as the role of power in contemporary society, the role of the media in distorting our notion of reality, or the writer's awareness of discourse as mediator of human experience.

(Collado, 1994: 545)

Collado notes that this type of fiction has been called «postmodern realism» and mentions the names of some contemporary American novelists that could be drawn together under this label: William Kennedy, Stephen Dixon, Don Delillo, Russell Banks and Eric Kraft. These writers elaborate a new conception of mimesis that does not take the world for granted. The «real world» is constructed from and by the «fictional world», and fiction becomes the mirror up to fiction. Postmodernism re-appropriates realism and uses and abuses realistic conventions together with metafictional techniques. In the last chapter of The Self-conscious Novel: Artifice in Fiction from Joyce to Pynchon, Stonehill comments on this recuperation of storytelling that is beginning to take place in contemporary fiction:

We are, I think, seeing a retum to character, to humanism, to story, but a return accompanied by a heightened awareness of the medium and its contingencies. «Wised-up story telling» might describe the result.

(Stonehill, 1988: 193)

When asking Eric Kraft whether there was always a preoccupation in his fiction regarding some postmodernist issues like the relationship between fiction and reality, the laying bare of realistic conventions or the dissolution of the self, he answered that those issues were to be found in his fiction but that in some parts of it he was "just being plain» ${ }^{4}$ because his characters had become realistic

4 ERIC KRAFT in the course of a lecture on his novel Where do You Stop?, and in a seminar on «Race, Class, Gender: American Postmodern Fiction», both held in April 1996 at the University of Zaragoza. 
enough for him. The combination of «mimesis» and metafiction has allowed for a new kind of realism to emerge that is not naive any more, and for a recuperation of plot and character.

The author of «Call Me Larry" is, as in the case of the other novellas compiled under the title Little Follies (1992), Peter Leroy. Peter met Eric Kraft in a dream Kraft had when he fell asleep in front of a German textbook in an overheated library in 1962 - a story Kraft is always willing to recount in his lectures. Peter says that in the course of the dream he inserted himself in the mind of Eric Kraft and that he has been there ever since. Peter Leroy is the name Kraft gave to his imagination.

In "Call Me Larry» there are three worlds that belong to apparently three different ontologies: the real world of Eric Kraft, the (fictional) real world of Peter Leroy and the (within a fictional reality) fictional world of Roger Drake. From a narratological point of view ${ }^{5}$ we can distinguish between three narrative levels: the level of the actual author, Eric Kraft, which is outside the story "Call Me Larry", the first level of fictionality, which corresponds to the author-narrator Peter Leroy, and the second level of fictionality, that of the third author, Roger Drake:

author: Eric Kraft

author-narrator: Peter Leroy

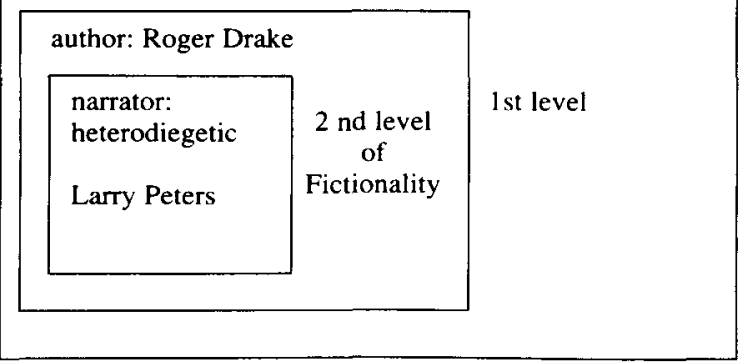

Real World

The Novella

"Call Me Larry"

The three authors employ three different types of narrators and relate to their fictions in different ways. Eric Kraft invents an author and the world that both he (the real author) and Peter Leroy (the fictional author) create is fictional for Kraft. But as he has said, this world made out of real and fictional elements is beginning to look real for him. Peter Leroy is an author and the

"I will be using Genette's terminology (1972). 
homodiegetic narrator of his narrative; apparently he is a realistic author and therefore his narrative is supposed to be mimetic for him, but as he tells us in the prefaces he inserts in each novella or each novel, a lot of what he narrates is fictional. Roger Drake uses a heterodiegetic narrator and he himself is as fictional as the fiction he is supposed to write, he is the invention of a publisher belonging to Peter Leroy's ontology.

In the light of this description of the novella's narrative structure, the three ontologies that can be distinguished may appear clearly distinct and differentiated from one another. The second level of fictionality, the Larry Peter's stories, is framed within the first level of fictionality, Peter Leroy's world, and the latter is framed within the pages that comprise the novella that the reader holds in his/her hands. Realistic fiction maintains the division between different narrative or ontological levels and the notion of awareness of the existence of a different level only works in one direction, from the level of "reality" to the most fictional level. In postmodernist fiction the knowledge of the existence of a different level works in both directions; for example, characters may address their authors or authors enter their fiction. In «Call Me Larry» metafictional «commerce» between the different worlds that have been described is not overt but «[...] a reader who [is] familiar with the series and its conventions» (CL 360, Peter Leroy commenting on the Larry Peter's stories), and, it could be added, with Eric Kraft's persona, is very likely to enjoy the realistic part of the novella at the same time as $s$ /he discovers the existence of elements - winks at the seasoned reader of Kraft's - that disrupt the borders between those worlds.

The intrusion of the figure of the fictionalised author in his/her own work is a metafictional technique that many modernist and postmodernist writers have used (Fowles, Nabokov, Muriel Spark, etc.). The figure of Eric Kraft does not appear directly in his fiction so as not to disrupt the illusion of realism, but in «Call Me Larry» he is undoubtedly present in many ways. He intrudes in the novella on the very first page, through a quotation of an actual quotation of a sentence that appears in «Call Me Larry»:

Eric Kraft... looks exactly like my mind's-eye picture of Peter Leroy: wiry build, wacky smile, bright eyes.

Susan Orlean «Getting Serial»

The Boston Phoenix

(CL 341)

The explanation for the feasibility of this quotation is realistic: the novellas were published separately in paperback some time before their compilation. But 
nevertheless, it is very unsettling, and very useful for the purpose of showing the precariousness of the divisions of the different worlds in the novella. The characteristics Susan Orlean has attributed to Peter Leroy first and to Eric Kraft second are in fact the characteristics that define the Peters' family: «Father and son shared the most pronounced Peters family features: a wiry build, a wacky smile, and bright eyes." (CL 358); an element coming from the second level of fictionality emerges to the «real world» and is finally inserted into fiction again. The question that comes to mind is «who is the author of this and the other two quotations?» In a less problematic way it is also slightly unsettling to hear many echoes of Kraft himself in Peter Leroy's words:

[...] I wanted to write a book about myself. Unlike many people who want to write books about themselves, I was embarrassed to admit it even to myself, and so I cast about for a way to write a book about myself without seeming to. (CL 379).

It may seem that Kraft (or Peter) is making fun of himself and of Peter Leroy when we realise that what we have in our hands is what Peter is describing to us:

I still keep trying to write that big book about myself, that book as rich and various as a good clam chowder, loaded with useful and interesting information, hilarious anecdotes, recherché allusions, philosophical speculations, intriguing stories, clever word play, important themes, striking symbols, creative sex, intricate diagrams, mouth-watering recipes, big ideas-(CL 387).

Contemporary critics agree that whereas in realistic fiction it was not licit to make use of the author in order to interpret his/her work, in postmodernist fiction, especially in self-conscious novels, the author together with the reader and the «real world», which belong to the world outside the novel, become intrinsic elements ${ }^{6}$. Whether it is Kraft himself or his persona that is incorporated in his fiction is unimportant, for they have become the same thing. Kraft himself has declared that he can no longer make the distinction: he has

"Brian Stonehill argues that if we practice «intrinsic criticism" (a term he uses to describe the critical posture adopted by the New Critics) instead of biographical, rhetorical, literary-historical of thematic criticism, that is, if the text is read strictly as text, the elements «author», «reader», "real world», and «literary history», must remain outside the scope of the analysis of fiction. However, if we apply the same analysis to a self-conscious novel, these four elements would have to be considered integral parts of it because «[t]he self-conscious text dramatizes and encapsulates its own context.» (1988: 5). 
forgotten which parts of his mind are memories and which ones figments of his imagination.

The frontier between the (real) fiction of Kraft's persona and the (fictional) reality of Peter Leroy is crossed once again in a self-parodical way. When Peter Leroy talks about the way in which he met and became Larry Peters he seems to be copying (or parodying?) Eric Kraft. Compare the tale Kraft himself has told many times about the way in which he «met» Peter Leroy, and the section in the book where Peter tells us about the way he «met» Larry Peters:

One cold winter afternoon in 1962, while dozing over a college German lesson, Eric Kraft dreamed up a nameless little boy sitting on a dilapidated pier, trying to bring the soles of his bare feet as close as he could to the surface of the water without actually touching it.

(Cover of Little Follies, 1992)

Peter in «Call Me Larry», just before «meeting» Larry:

Some eight years later, on a cold February afternoon during my sophomore year at Hargrove University, I sat in Cranston Library, trying to study for a mathematics examination. [...] the heat, the odors, and Robert Meyer's prose style put me to sleep nearly at once. I had been sitting with my feet up on a table, and I had leaned backward in the chair until it rocked on the back legs only. When I woke, I was sitting on a dilapidated wooden dock. I was barefoot, and I was playing a game with the surface of the water [...] I was trying to bring the soles of my feet as close to the surface of the water as I could without touching it. (CL 374-375)

In the same way as Kraft tells in his lectures that he does not know which parts of the dream he asserts he actually had are true and which ones have been invented by his imagination, Peter Leroy will tell us that his memory of Larry Peters «was not a memory: I was making it up.» (CL 379). Finally, when Peter complains once again to Porky White about his desire to write «that big book about myself» (CL 387) and Porky White advises him to create «a new dummy»: "What you need," said Porky, «is a new dummy. You've got a dummy called Larry. Now you need another dummy. Let the dummy write the big book.»(CL 387), the neat narratological description of the novella begins to fall to pieces: if Eric Kraft is nothing but Peter Leroy's dummy, how can we know which is the real and which the fictional world?

The implication of considering the possibility that the author and the reader might constitute in fact a first fictional level, as the novella seems to 
suggest, is that Peter Leroy's ontology starts appearing more tangible. The realistic mode the narrator uses in the description of his adventures and the presence of long and detailed description contribute to this project. For the reader familiar with Kraft, the recurrence of some elements in all the novellas and the familiarity with almost every character reinforces the notion of the actuality of Peter Leroy's world: clams, the clam chowder, studebakers, Babbington, the Bolotomy bay, among others, are always present in them. The conviction that his world is almost real is intensified by the attitude of the narrator himself. The adult narrator consciously distances his narrative from the fiction of the Larry Peters' books. He does so in an overt way when he mentions that the characters in those books could do almost everything or that their lives were full of amazing adventures, something which never happened to him as a child, or in a more subtle way by practising literary criticism on them: "The reader saw this quality at once [...]" (CL 357), "The reader could be sure, at the beginning of a Larry Peters book, that [...]" (CL 359), or «The 'dry land sailboat' was the basis for the subplot in The Thief of Time. In that book, [...]» (CL 360). Peter Leroy is trying to build a frame that will establish a division between his world and that of Larry Peters, but the reader cannot fail to notice the fragility of such a frame when $s /$ he recognises the similarities between both worlds. For instance, it cannot be coincidental that the next knickknack Edgar Peters is going to manufacture is a glass clam, one of the most recurrent elements in Peter Leroy's narration.

There is a section in the Larry Peters' stories that breaks the frame Peter has taken pains to erect and which could be considered a mirror image of the whole novella. It exemplifies the notion that some contemporary fiction is still aiming at holding a mirror up to fiction. One of Larry's project consists in placing a painting before one of the windows in the Peters' living room. Larry explains:

«Before, you would have seen a familiar view that offered you no escape from your own tedious life because there was nothing interesting in it. [...] But now you see something interesting, and you have a whole flock of things to wonder about». He began suggesting questions, indicating details in the painting as he did so. "What island is that? How did it get there? Who built the hotel? Why was it abandoned? Is anyone living there now? If so, who? And what about that rowboat that sunken rowboat at the end of the dilapidated dock?» (CL 361-2)

The reader will not fail to recognise the clue that the last two words offer. The model for Larry's picture is Peter Leroy's island and the hotel is his and Albertina's business. The sunken boat comes from a memory of childhood of 
Peter's mother which Peter might have inherited. Larry has not only hung a mirror-picture on a wall but opened a window into a world making us reconsider the relationship between what seemed to be two independent ontological levels. The reader will discover the logical explanation for this towards the end of the novella; Peter Leroy will become Roger Drake, he will revise all the previous books of the Larry Peters' series and re-write them from his point of view: «I have also included details and props from my life in Larry's" (CL 385).

Peter Leroy is not a realistic narrator; along the prefaces of his novellas he openly admits he has invented some characters or altered some facts. Eliza Foote, his friend Raskolnikov and all his family including Arianne, Matthew Barber, the protagonist of Reservations Recommended (1990) are all figments of Peter's imagination. Nevertheless he seems to be more interested in telling his story and in his characters and their lives than in playing metafictional games or in formal experimentation. Peter constructs the illusion of reality and breaks it in his prefaces, only to re-construct it again. He admits to having invented some of his characters; but in presenting them in a realistic way -in terms of liberal humanism - with lives of their own and with the ability to take their own decisions, and in placing them together with characters that in Peter's level of fictionality are real, he invites readers to suspend their disbelief and enjoy storytelling. And in the same way as he tries to distance his narration from the fiction of the Larry Peters' books, he will set out to unveil the fictionality of their characters in order to reinforce the actuality of his own.

The characters Roger Drake has designed are «just an artist's trick» (CL 348). Their artificiality is manifest since, as Peter Leroy will discover when he becomes the last Roger Drake, they have been drawn, in the same way as the stories, from «character dossiers and plot outlines that the publisher himself supplied» (CL 384). This is the result of a combination of fragments and the characters that emerge from them are full of gaps the reader will have to fill. By means of parodic exaggeration, they bring to light the method currently used in realistic fiction for the formation of character. Realistic characters are intended to represent «real people» or people from the world outside fiction. They have to be concrete, individualised figures in which the reader is supposed to discover an essence to identify with (Furst, 1992: introductory chapter). But the Larry Peters' characters are not life-like figures but stereotypes with which the reader cannot identify. In order to make identification possible, the reader will have to fill the gaps in them with elements drawn from his/her own world. Therefore these elements will become part of the ontology of the fiction. This is what Peter Leroy says about the character of Lucinda:

Lucinda's character was wildly variable. She'd act like one of the guys at one time, grow shy and retiring at another, become brazen and 
sarcastic, headstrong, cautious, and who-knows-what-all by turns. Her appearance was never described in full, and even the fragments that the reader was given now and then, glimpses, as it were, through a curtain parted by a puff of a summer night's breeze, were vague, more tantalising than satisfying. This vagueness was, I concluded, deliberate and wise, since the reader was, thanks to the lack of details about her appearance, allowed, even encouraged, to construct his own Lucinda from bits and pieces of girls he knew, or a girl he had merely glimpsed [...] (CL 366).

In these stories, instability does not only affect the characters, it is also the main characteristic of their author, Roger Drake. Peter tells us how he got to know that the author whose name appeared on the covers of the Larry Peters' series «was himself a work of fiction» (CL 384). «Roger Drake» was the name that the several authors of the books adopted in turn. What may look like the statement of the disappointment of the young Peter Leroy as a character in his story, in the mouth of the adult narrator becomes a declaration of Peter's own ficticiousness and, by extension, an invitation to question the existence of the actual author of "Call Me Larry", Eric Kraft. This is an example of how in postmodern fiction, the most fictional level in a narrative can make statements on the levels that include it and of whose existence it is not supposed to be aware.

Unlike Roger Drake's characters, Peter's give the impression of being almost fully-rounded individuals. The narrator does not have access to their minds but their actions show that they possess the abilities of free will and moral choice. Nevertheless, we already know that at least some of them have literally been created by Peter. Therefore, Peter is telling us that his characters are as fictional and as fragmented as the Roger Drake characters but at the same time he is asking us to suspend our disbelief for the benefit of storytelling. After contemporary critics have disclosed the fictiveness of the universal humanist subject, the representation of character in literature and in the visual arts has become problematic. Many feminist writers and critics have tried to demonstrate how the conception of the so-called universal subject is gendered. If the representation of the male subject is controversial, the female subject as portrayed in fiction is shown to be a representation of male desire (Carter, 1972 \& 1994; Hutcheon, 1989). The character of Lucinda in «Call Me Larry" is, as we have seen, the most variable character in the Larry Peters' series. Peter also suggests that the character of Marie, the Peters' maid, was so full of gaps that «[m]ost of [his] ideas about Marie came from outside the books themselves, from other sources and from my imagination» (CL 369). In the other novellas, the characters of Eliza Foote and Arianne have been constructed, as a matter of fact, from a male point of view. Peter invented Eliza 
because, as his father says «Dudley need[ed] a woman» (Kraft 1992a: 3). And in Where Do You Stop?, Peter imagined a sister for his friend Raskolnikov so that he himself could be in love with her.

The text, therefore, acknowledges the difficulty of representing the subject in fiction. It reveals its own tricks but it does not abandon character. Kraft's characters are still constructed in humanist terms. They do not share the features that, according to Thomas Docherty (in Smyth, 1991) or Brian Stonehill (1988: chapter 2), distinguish postmodern characters. They do not contradict themselves or dissolve in the middle of the narrative, they bear recognisable traits that are repeated from novella to novella, they are consistent and coherent in spite of being made out of fragments. They even seem to have an essence. Due to this, postmodern realism still allows for the aspiration towards wholeness and totality. The novella form Kraft uses is a way to tell pieces of stories without having to construct a whole structure but Kraft has confessed that he could not start working until he found a grand design to include everything. Every fragment that we read is a contribution to the totality. Postmodern fragmentation is acknowledged, the character's ficticiousness is laid bare but, nevertheless, the illusion is maintained.

\section{REFERENCES}

CARTer, ANGela (1982-1972): The Infernal Desire Machines of Doctor Hoffman. London: Penguin.

- (1994). «The Merchant of Shadows». American Ghosts and Old Wonders. London: Vintage.

Collado. Francisco (1994): «Postmodern Fragments and Scientific Realism: Eric Kraft's 'Ficciones'». Actas XVIII Congreso de AEDEAN, pp. 543-549.

DOCHERTY, THOMAS (1991): «Postmodern Characterization: The Ethics of Alterity».

Postmodernism and Contemporary Fiction. Ed. Edmund J. Smyth. London:

Bastford, pp. 169-188.

Furst, LILIAN R. (1992): Realism. London \& New York: Longman.

GenetTe, GéRARD (1983-1972): Narrative Discourse: An Essay in Method. New York: Cornell UP.

HutChEON. Linda (1990-1989): The Politics of Postmodernism. London: Routledge.

- 1988. A Poetics of Postmodernism. New York \& London: Routledge.

Kraft. ERIC (1992a): «Call Me Larry». Little Follies: The Personal History, Adventures, Experiences and Observations of Peter Leroy (so far). New York: Crown, pp. 340-388. 
- (1992a): «My Mother Takes a Tumble». Little Follies: The Personal History, Adventures, Experiences and Observations of Peter Leroy (so far). New York: Crown, pp. 340-388.

- (1992b): Where Do You Stop? The Personal History, Adventures, Experiences and Observations of Peter Leroy (continued). New York: Crown.

- (1990): Reservations Recommended. New York: Crown.

SARUP, MADAN (1988): An Introductory Guide to Post-Structuralism and Postmodernism. Hemel Hempstead: Harvester Wheatsheaf.

Seed, David (1991): «In Pursuit of the Receding Plot: Some American Postmodemists». Postmodernism and Contemporary Fiction. Ed. EDMUND J. SMYTH. London: Bastford, pp. 36-53.

Stonehill, Brian. (1988): The Self-Conscious Novel: Artifice in Fiction from Joyce to Pynchon. Philadelphia: University of Pennsylvania Press.

Waugh, Patricia (1984): Metafiction: The Theory and Practice of Self-Conscious Fiction. London and New York: Routledge. 